\title{
DOI: 10.1515/orga-2015-0018 \\ Predictors of Users' Satisfaction with E-payment System: a Case Study of Staff at the University of Ilorin, Nigeria
}

\author{
Adeyinka Tella, Isah Abdulmumin
}

University of Ilorin, Department of Library and Information Science, Nigeria
tella.a@unilorin.edu.ng, abdulmumin.isah@yahoo.com

\begin{abstract}
Background and Purpose: Many organisations are using the e-payment system; however, its effectiveness has not been determined particularly in the Nigeria context. The University of Ilorin as educational organisation started using e-payment system in 2010 and up till now there has been limited or no study conducted to examine whether or not workers are satisfied with the new payment system together with other related ones they are familiar with. It is in the light of this that this study examined users' satisfaction with the e-payment system at the University of Ilorin, Nigeria.

Design/Methodology/Approach: A sample of 260 academic and non-academic staff was taken from six out 12 faculties that made up the university. Using a survey research approach data was collected with a modified questionnaire. Five research questions were developed to guide the study.

Results: The results revealed that, respondents (93.5\%) were adequately satisfied, satisfied and moderately satisfied, while, only $(6.5 \%)$ of the respondents were less satisfied and dissatisfied. Perceived speed was identified as the characteristics users mostly satisfied with, followed by system security, traceability, and convenience. Moreover, there is significant correlation among the entire e-payment characteristics/factors (perceived speed, security, anonymity, traceability, perceived ease of payment, and convenience); and that all the six factors jointly predict users' satisfaction with the e-payment system. In order of magnitude of the prediction/contribution to e-payment, users' satisfaction, perceived speed made the most significant prediction/contribution.

Conclusion: Based on the findings, the study concluded a considerable percentage of the respondents (93.5\%) are satisfied with the e-payment system at the University of Ilorin, Nigeria. In lieu of this therefore, there is need to improve the e-payment system so that all and sundry could be satisfied.
\end{abstract}

Keywords: users' satisfaction, e-commerce, electronic payment system (EPS), salary, University of Ilorin

\section{Introduction}

Information communication technology (ICT) revolution has resulted to the emergence of e-commerce which has also created new financial needs which in many cases cannot be effectively fulfilled by the traditional payment systems. In this regard, nearly all interested stakeholders are exploring the varieties of electronic payment system and issues surrounding it and digital currency.

In the context of this study, the e-payment system is in form of a payroll application which the employer (the university) uses in money transaction with other users (the staff) to effect payment instead of cash. Other ex- amples are e-payment solutions for vehicle licensing and revenue collection, InterSwitch ATM, Bank transfer, Valuecard, etc. all of which academic and non-academic staff are important users. These users use the system anytime of the month and mostly monthly for payment of salary or reward/remuneration of services rendered by any staff, renew of vehicle papers, etc. The system is not an out of box application but rather a customised developed application which users instructed to effect payment and which the receiver is alerted immediately such payment is made.

In the year 2010, the University of Ilorin, Nigeria introduced electronic cheque payment for the payment of salaries to the workers to replace the old form of payment which has its advantages and disadvantages for the 
(staff) customers and merchants (University's Banks). The advantages of the old method include but not limited to customers opportunity of collecting cheque by self and deposit directly by self into their account while the disadvantages include long processing/preparation of salary vouchers, high incidence of bounce cheques, lack of an electronic means of verifying valid cheques, the poor interconnection of banks and a lack of an electronic cheque clearing system among others.

As revealed in the literature, this e-payment system (EPS) has number of characteristics such as security, acceptability, perceived enjoyment, and perceived speed, ease of payment, convenience, cost, anonymity, control, and traceability (Abrazhevich, nd*; Tella, 2012; Tella and Olasina, 2014). Meanwhile, the new e-payment system has its attendance challenges including ignorance on the part of the users, poor banking culture, lack of trust, illitracy and the love for status quo to mention but just few.

Many organisations have been using e-payment system; however, its effectiveness has not been determined particularly in the Nigeria context. The University of Ilorin started using this system of payment in 2010, but unfortunately, there has been no single study conducted to examine whether or not workers are satisfied with the new payment system. The factors that lead to the stakeholders' satisfaction concerning the e-payment system have not been established.

Available relevant studies focus only on the voluntary use of an e-payment system; however, the mandatory settings are also interesting area to be studied. The relationships have been consistently confirmed in voluntary context, albeit, it is not clear whether the same relationships hold in mandatory settings such as the University of Ilorin. A mandatory use of e-payment system environment is defined as one in which users are required to use e-payment system in order to perform better in their jobs (Brown et al., 2002). As it has been observed, some research are located in a mandatory use of e-payment settings for initial IS acceptance (e.g. Venkatesh et al., 2003). However, very few studies are found in mandated IS satisfaction domain (Sorebo and Eikebrokk, 2008).

These are considered as knowledge gaps that need to be filled. In the light of this therefore, the researcher considers it necessary to determine how satisfied the staff of the University of Ilorin are as far as the use of e-payment system for the payment of their salaries since 2010 is concerned. Not this alone, it is also important to determine how satisfied the users are with other related e-payment products they are familiar. It is assumed that the findings from the study will assist in improving the value of this system of payment. The outcomes might also interest other stakeholders to eventually emulate the gesture thereby commencing the use of e-payment system for the payment of salaries to their staff and other monetary transactions. Thought the study is limited to the University of Ilorin, Ni- geria; however, the outcomes from the study can be helpful to other universities in the country who are in the planning stage of introducing e-payment for workers' salary.

\section{Literature Review}

\subsection{E-payment System (EPS)}

The revolution of ICT is now given room for the 'e' in everything including e-banking, e-transaction, e-registration, e-shopping, e-payment, e-learning, e-library, etc. This study only focuses on e-payment. E-payment is considered a part of e-commerce transaction that includes electronic payment for buying and selling goods or services offered on the Internet. In other words, it is a payment system in which monetary value is transferred electronically or digitally between two entities as compensation or consideration for the receipt of goods or services. An entity in this regard refers to a bank, business, government or even an individual customer (Tan, 2004, 3). According to this author, any payment not affected by paper-based instruments is considered an e-payment transaction. It should be noted that advances in technology in some parts of the world make it possible for cheques to be treated as e-payment instruments.

E-payment users have the opportunity of sending or instructing payment orders through electronic terminals either through selves or by authorizing other people, to realize money payment and capital transition. E-payment subsumes online payment, telephone payment, mobile payment and self-service terminal payment. E-payment users refer to users who use e-payment channels and tools to complete payment behaviour. In a broader sense, electronic payment systems can be categorised into four (Anderson, 1998). These are: Online Credit Card Payment System, Online Electronic Cash System, Electronic Cheque System, and Smart Cards based Electronic Payment System. Each category has merits and demerits both for the customers and merchants. There are number of criteria peculiar to these payment systems such as security, acceptability, convenience, cost, anonymity, control, and traceability. Tan $(2004,3)$ on his own categorised e-payment transactions into three segments: retail e-payment, corporate e-payment and wholesale e-payment. He explained that the retail e-payment segment includes three types of transactions: consumer-to-business $(\mathrm{C} 2 \mathrm{~B})$, business-to-consumer, and peer-to-peer (P2P) (or consumer-to-consumer $\mathrm{C} 2 \mathrm{C}$ ). The $\mathrm{B} 2 \mathrm{~B}$ transaction covers the payment of wages or salaries from employers to employees or ETFs such as refunds of monetary value from business to consumer. This exactly is the type focused in this study. Transformation in electronic payment system aroused as a result of the development in EFT (Electronic Fund Transfer) technology. EFT is a technology that enables the 
transfer of funds from the bank account of an individual or organization to another. Similarly, EFT is the action of using this technology (Cavarretta and de Silva, 1995).

\subsection{User Satisfaction}

One of the most important dependent variables used in measuring the success of information system due to the non-volitional status of the majority of the systems is user satisfaction. User Satisfaction (US) is concerned with examining the successful interaction between the IS and its users. According to Doll and Torkzadeh $(1988,261)$ user satisfaction describes 'an affective attitude towards a specific computer application by someone who interacts with the application directly'. In summary, user satisfaction can be regarded as a function of perceived ease of use and perceived usefulness, and so it's assumed that if users are fully satisfied with an information system, that system is a success.

In other words, it is observed from literature on information system success and satisfaction that common variables used to measure information system success include system effectiveness, users' satisfaction and system adoption or acceptance. It is on the basis of this that user satisfaction was used in this study as measure of e-payment success. This is in congruent with (Delone \& Mclean, 2003) position that any of net Benefits, (Intention to) Use, or User Satisfaction can be used as dependent construct or factor of system success.

\subsection{Information Systems and Users' Sat- isfaction Related Studies}

Tijani and Ilugbemi (2015) examine the impact of electronic payments channels (EPC) on National development (ND). The survey focused current and savings accounts customers of deposit money banks in Nigeria. A total of 120 copies of questionnaire were administered in 6 different banks in Ado-Ekiti metropolis. Ninety-Eight (98) copies of questionnaires were returned for processing. Inferential statistics specifically chi-square was used to analyzed the collected data. The results demonstrate that electronic payment channels (EPC) have impacted on the economy and therefore contributing positively to national development (ND). Based on this finding, it was recommended among others that the Central Bank of Nigeria (CBN) should introduce other e-payment products for the promotion of trade and commerce in Nigeria; and that they should embark on rigorous campaign for the total adoption of e-payment products especially at the grassroots level.

Alao and Sorinola (2015) investigate the customers' satisfaction with the ongoing cashless policy in Ogun State, Nigeria with a survey of bank customers in Abeokuta.
Questionnaire was used to gather data from the respondents while the collected data was analyzed using descriptive statistics. The formulated hypotheses were tested with correlation coefficient. The findings reveal that cashless policy contributed significantly to customers' satisfaction in Ogun State. The study concluded based on this finding that the cashless policy is customer friendly and progressive. Therefore, it was recommended, among others, that infrastructures should be improved to ensure easy operation of the policy in Ogun state and Nigeria as a whole.

Irani, Sivarajah, Molnar and Lee (2014) measured citizen satisfaction with the electronic London Congestion Charging (LCC) payment system offered by Transport for London (TFL) in the United Kingdom (UK). The study reported the results of a survey of 500 users of the TFL LCC online payment system. Four dimensions emanated from COBRA model that comprise the cost, opportunity, benefits and risk assessment constructs were used to capture data on satisfaction.

The study demonstrated that most citizens using the LCC electronic service are satisfied with the service and that the service meets their essential needs. The study concluded that the feedback from the respondents can be utilized to determine the areas that require additional improvement in the current electronic LCC e-service system and its influences on user satisfaction. The Irani et al. (2014) study was conducted in the UK focusing on London Congestion Charging (LCC) payment system by transport for London which does not even exist in Nigeria while the current study on the hand focus on the e-payment system, a newly adopted system of payment for the workers' salary.

In another related study, Adeyemi and Ola (2014) investigated the impact of internet banking on the customer satisfaction level in the banking sector of Nigeria. A structured questionnaire was used to collect data from a sample of 90 customers of 10 different banks. Data collected were analyzed using regression analysis with the aid of Statistical Package for Social Sciences (SPSS) software.

The results, revealed among others, that the independent variables (i.e. internet banking and quality service) were significant joint predictors of customer satisfaction $(\mathrm{F}(2,87)=91.3035 ; \mathrm{R} 2=0.677 ; \mathrm{P}<.01)$. The independent variables jointly explained $67.74 \%$ of variance of customer satisfaction. The study recommended based on the findings that banks' customers should be educated on how to make use of internet banking products and that Nigeria government should also enact law that will govern internet banking which will not allow unfair and deceptive trade practice by the supplier and unauthorized access by hackers.

Tella and Olasina (2014) examined the technology acceptance model (TAM), to predict the users' intentions to continue using e-payment system. The hypothesized model was validated empirically using a sample data collected from a modified e-payment questionnaire. A simple ran- 
dom sample technique was used to select 250 academic and non-academic staff at the University of Ilorin, Nigeria. The results show correlation among perceived usefulness and attitude to use, perceived ease of use and perceived usefulness, perceived ease of use and attitude; perceived enjoyment and continuance intention to use, speed and actual use. Additionally, attitude, satisfaction and actual use were all associated with continuance intention. Moreover, all the nine e-payment predictive factors together made $65 \%$ of e-payment continuance intention, and similarly; perceived usefulness, perceived ease of use, enjoyment, speed; perceived benefits, user satisfaction, actual use and attitude are good predictors of e-payment continuance intention.

Olanipekun, Braimo and Ajagbe (2013) examined the impact of e-banking on human resource performance and satisfaction. Questionnaire was used to source for data from fifty randomly selected respondents which constitutes the sample while Chi-square analysis was used to analyze the collected data. The study demonstrated that introduction of electronic banking has impacted positively on the bank's human resource performance. It has also resulted to improved efficiency and effectiveness of service delivery by bank workforce and has enhanced customers' satisfaction. The study recommended that critical infrastructures that aid the usage of e-banking products should be provided.

Hamid and Cheng (2013) identified young adult's perception of e-payment risk and their behaviour towards different payment methods. Survey questionnaire was distributed to gather data from the students of tertiary institutions in a metropolitan city of Malaysia. The findings showed significant difference in perceived risk between cash and e-payment but less significant in terms of volume of purchase.

Tella (2012) synthesized the technology acceptance model (TAM) to explain and predict the success of e-payment system using users' satisfaction as dependent variable. Data was collected using a modified e-payment questionnaire. The sample for the study consisted of 74 teaching and non- teaching academic staff from the Faculty of Communication and Information Sciences, University of Ilorin, Nigeria. The results revealed correlation among perceived benefits, perceive enjoyment, speed; service quality, perceive ease of use and actual use and e-payment success. Moreover, the entire seven e-payment constructs together made $69 \%$ of e-payment system success. In addition, perceived benefits, perceive enjoyment, speed; service quality, perceive ease of use and actual use are good predictors of e-payment system success. The study pointed out that instead of making use of self-reported measure, future research should consider developing more objective and accurate measure for the determining the e-payment success.

Adeoti and Osotimehin (2012) investigated the consumers' satisfaction with adoption of e-payment system in
Nigeria. Data for the study was collected from bank customer. Generally, the result indicated that less than $10 \%$ of the consumers were satisfied with the speed of transaction, extent of service provided by the merchants, awareness, and security. The study called for improvement of the consumer interface in order to achieve the objective of the cashless economy which the country is aiming at.

Chavosh, Halimi and Espahbodi (2011) investigated bank customers' satisfaction with e-payment services in Malaysia. Through a review of literature, the research considered issues associated with electronic payment and discussed its advantages. Thereafter, a comparative analysis was provided by looking at the satisfaction rate with e-payment services in Malaysia's Banking Industry between two sample groups in Penang.

These two groups consist of respondents who are holders of Degree and Non-Degree users of electronic payment bank services. The results of the study demonstrated that in spite of inconveniences, cost and some security concerns both groups of respondents indicated high level of satisfaction with e-payment services. The study found inconvenience to be the most important challenge identified by Non-Degree Holders, while Degree Holders were more concerned about security issues. The study concluded by pointing to the fact that the outcomes from the research can be used as platform for bank manager and e-payment companies to improve their systems and services. This study differs from the current research in terms of setting. The former was conducted in the banking sector while the later was conducted in an academic environment.

Ayo, Adewoye and Oni (2010) in a review and evaluation of the state of e-Banking implementation in Nigeria and the influence of trust on the adoption of e-Payment from the perspective of extended technology acceptance model (TAM). The study considered factors such as organizational reputation, perceived risk and perceived trust in the management of banks as they enhance customer loyalty. The results show that perceived ease of use and perceived usefulness are not only antecedent to e-banking acceptance, they are also factors to retain customers to use e-banking system, boost organizational reputation, perceived risk and trust. Compare to the current study, Ayo et al. (2010) only focus on review and evaluation of e-banking from the perspective of an existing model (TAM). However, the current study focuses on satisfaction with e-payment system and the likely factors that determines it.

In his own study, Khan (2010) examined the dimensions of ATM (automated teller machine) service quality and its effect on customer satisfaction. Data for this study was gathered through a questionnaire administered to a sample of 500 customers of multinational and national banks. Through multiple regression analysis, the findings demonstrate that convenience, efficient operation, security and privacy, reliability and responsiveness are significant dimensions of ATM service quality. Similarly, ATM ser- 
vice quality contributes significantly to customer satisfaction. The study is a significant contribution to the quality management literature because limited empirical studies focusing this aspect of the banking sector in Pakistan are available. The current study focuses e-payment system which also related to banking. However, none of the factors considered influencing e-payment satisfaction was captured in Khan study.

Saha et al. (2010) investigated citizen satisfaction as a determinant of e-government success and also explore the relationship of satisfaction with e-government service quality. Analysis of data reveals that $43 \%$ of the variance among the factors of e-service quality, and usage is explained by citizen satisfaction. E-service quality was found to be related with citizen satisfaction. Similarly, compare to privacy in determining e-service quality, efficiency, responsiveness and web assistance was found to be of more importance.

Use was reported to be significantly correlated with citizen satisfaction. The findings contribute to the understanding of the major factors that influence citizens' needs and level of satisfaction with the tax services and help improve the service delivery process. However, none of the variables focused in the study relates to security, perceived speed, and ease of payment, convenience, anonymity, and traceability which are the target in this study. The suggestion for further exploration of other quality dimensions such as system and information quality prompts this current study.

Chen, Chen and Chen (2009) in an integrated model explain individual's continuous use of SSTs concepts of technology readiness (TR), technology acceptance model (TAM), and theory of planned behaviour (TPB). Data for the study was collected from 481SST users. Through structural equation modelling, the study reveals that consumers' satisfaction significantly impacts continuance intention, while the perceived usefulness, perceived ease of use, subjective norm (SN), and perceived behavioural control (PBC) simultaneously influence satisfaction. Other significant motivators of satisfaction reported are optimism and innovativeness.

Contrarily, discomfort and insecurity which are technology readiness inhibitors have significant negative influence on continuance intention towards adopting SST services. Different from the current study, the author focused on self-service technology while the current study focus on e-payment system and expert service technology. Similarly, the former study combined satisfaction with continuance intention while the current study focused only satisfaction.

Jung-Yu and Ching-Tsung (2008) explored factors affecting corporate customer satisfaction with e-banking (CCSEB) one of the variables in e-banking services success. A sample of 178 respondents was surveyed from Taiwan companies. The results demonstrate that factors such as environmental, organizational, and globalization significantly affect customer satisfaction with e-banking. Furthermore, the study reported existence of relationship between customer satisfaction and post-usage favourite behaviour. This study differs from the current study in terms of focus and variables. Similarly, it observed that research on e-payment is very limited compare to the e-banking. Hence, this study is an attempt to add to research and literature especially from the Nigeria context.

Extant review on information systems research has revealed many factors determining users' satisfaction with an information system. They include for instance, services quality, security, perceived speed, ease of payment, perceived benefits, actual use, attitude toward use, technical support, intention to use, experience, perceive ease of use, self-efficacy, system interactivity, etc.

This study only focuses on characteristics or factors peculiar and relevant to e-payment system including security, perceived speed, and ease of payment, convenience, anonymity, and traceability which most previously related researches have ignore. In addition, literature has also reveals that most of the related studies on e-payment system adoption or satisfaction were conducted in advanced nations while very limited ones are conducted in the developing nations. Conducting this research is considered important in view of the fact that it is an addition to literature from the perspective of a developing nation. The study therefore attempts to examine whether the six identified characteristics are capable of predicting users' satisfaction with the e-payment system at the University of Nigeria.

As mentioned before, the University of Ilorin started using this system of payment in 2010 and up till now there has been limited or no study conducted to examine whether or not workers are satisfied with the new payment system. It is in the light of this that this study examined users' satisfaction with the e-payment system at the University of Ilorin, Nigeria. To achieve the objective of the study, the following research questions were developed.

1. What dimension of e-payment system users mostly satisfied?

2. What is the overall level of users' satisfaction with the e-payment system?

3. Does inter-correlation exit among the factors and users' satisfaction with e-payment system?

4. Which of the e-payment (characteristics) factors best predict users' satisfaction with e-payment system?

5. What is the joint contribution of each of the (characteristics) factors to users' satisfaction with e-payment system? 


\section{Methodology}

A pure quantitative method using survey design was adopted for the study. The population comprised the academic and non-academic staff users of e-payment system at the University of Ilorin Nigeria. Currently, the total of academic and non- academic staff in this university stands at approximately 1600. A simple random sample technique was utilized to select 260 academic and non-academic staff from six faculties out of 12 faculties at the University of Ilorin. This sample selection was done during a gathering that involved all the staff in the university (academic and non-academic). Coincidentally, the selected 260 staff were from only six faculties. This represents the sample for the study.

\subsection{Instrument}

A modified questionnaire was used for the collection of data. Items in the questionnaire were adapted from questionnaires or scales used in previous relevant studies (e.g. Adewoye and Oni, 2010; Adeoti and Osotimehin, 2012; Adewoye, 2013, Tella and Olasina, 2014; Abrazhevich, $\left.\mathrm{nd}^{*}\right)$. The modification was done by rewording some of the contents to suit the purpose of this study. For instance, security item - most secure payments: paying by invoice MODIFIED to e-payment system is the most secure payment: paying by invoice; while anonymity item - never refrain from paying because of the fact of revealing identity when paying MODIFIED to I will continue using e-payment system because of identity revelation during payment. Table 1 provides the detail of how source of the items.

The questionnaire was divided into two sections. Section A requires respondents' socio-demographic data while section B contained the items. This section was sub-divided into parts (B1-B7) based on the variables/factors focus in the study. Table 1 shows the relevant studies where items in the sub-parts were adapted. The sub-part of the questionnaire featured items on each variable as stated above.

Each sub-part featured four items. This gives a total of 28 items in all. The response format follow a four point's Likert type scale ranging from Strongly Agree (4) to Strongly Disagree (1). The mid-point was not included to overcome 'I don't know' and indifferent choice which may distort the results of the study (Hussein et al., 2007). See the appendix for the details on items.

\subsection{Validity and Reliability}

Since the items were adapted from previous questionnaires used in related studies, it is believed that such might have undergone validation process. This in part justifies the validity of the questionnaire. However, after development, the questionnaire was given to two experts who are knowledgeable in IS research for scrutiny. The questionnaire was modified and reworded based on the suggestions by the experts. To determine the reliability of the questionnaire, it was administered on 20 respondents who did not eventu-

Table 1: Specification of Studies where Items were adapted and modified

\begin{tabular}{|c|c|c|}
\hline $\begin{array}{c}\text { Serial } \\
\text { Number }\end{array}$ & Factors/Variables & Relevant Studies where adapted \\
\hline B1. & Security & Adewoye, 2013; Adewoye \& Oni, 2010 \\
\hline B2. & Perceived speed & Adewoye \& Oni, 2010; Adeoti \& Osotimehin, 2010; Tella and Olasina, 2014 \\
\hline B3. & Ease of payment & Tella \& Olasina, 2014 \\
\hline B4. & Convenience & Adewoye, 2013 \\
\hline B5. & Anonymity & Adewoye, 2013; Abrazhavich nd* \\
\hline B6. & Traceability & Abrazhavich nd* \\
\hline B7. & $\begin{array}{c}\text { Users' satisfaction } \\
\text { (dependent variable })\end{array}$ & Tella \& Olasina, 2014 \\
\hline
\end{tabular}


ally participate in the study. A test-retest reliability method of three weeks interval was embarked upon. Data collected was subjected to Cronbach Alpha and the reliability coefficient returned an $\alpha=0.92$ for the overall questionnaire while the reliability coefficient of the sub-scale returned the following: Security $r=0.88$; Perceived speed $r=0.79$; Ease of payment $r=0.82$; Convenience $r=0.76$; Anonymity $r=0.83$; Traceability $r=0.75$ and the Users' satisfaction section 0.89 .

\subsection{Procedure of Administration}

The selected 260 staff were followed up to their faculty. These respondents were administered the instrument in their respective faculties. The questionnaire administration covered six days (a day for each faculty). Informed consent of the respondents was sought and they were all given voluntary opportunity to participate in the study. Responses were collected immediately except on special arrangement with the researcher. A total of 260 copies of questionnaire were administered and all were returned completely filled and good for data analysis. This absolute return rate was achieved because a day was earmarked to capture data in each faculty, cooperation of respondents and through proper monitoring; no attrition was recorded.

\subsection{Data Analysis}

Collected data was analysed using descriptive statistics including mean, percentages and frequency count, and some inferential statistics like multiple correlation, Anova and multiple regressions were also performed to determine which of the factors best determine users' satisfaction with the e-payment system. Percentages and frequency count were used to be able to determine the distribution of respondents and overall satisfaction of respondents with e-payment system. Descriptive statistics was used to identify the dimension of e-payment users mostly satisfied. Research question 1 was answered using descriptive statistics, percentage and frequency and multiple correlation. Research question 2, and 3 were answered using Anova and multiple regression and beta weight while research question 4 was answered by using frequency and mean and research question 5 was answered using percentage and frequency. The characteristics of the sample and other results are hereby presented.

\section{Results}

The demographic information of respondents who took part in the study in Table 2 reveals that $146(56.2 \%)$ were male while $114(43.8 \%)$ were female. Moreover, the demographic information on the respondents' age reveals that 55 respondents representing $(21.2 \%)$ have their age fall within 21-30 years of age; 55 respondents (21.2\%) have their age fall within the age group of 31-40 years. A total of 60 respondents $(23.1 \%)$ have their age fall within the age group of 41-50 years and 70 respondents (26.9\%) have their age fall within 51-60 years while 20 respondents (4\%) have their age fall within 61 years and above. On the respondents years of experience, the results indicate that majority of the respondents $110(42.3 \%)$ have between $0-10$ years of working experience.

This is followed by 90 respondents $(34.6 \%)$ who have their years of working experience between $11-20$ years; 35 respondents representing $(13.5 \%)$ have $21-25$ years of working experience and 25 respondents $(9.6 \%)$ have more than 31 years and above years of experience. Interesting demographic information is the respondents' educational qualification. The results on this show that 100 respondents hold ordinary national diploma (OND) and National certificate in education (NCE) representing (38.5\%). Respondents who hold Bachelor degree are 60 (23.1\%) while those who hold Masters' degree and Ph.D. each amounted to $50(19.2 \%)$ respectively.

Responses to all the dimensions provided were obtained to answer research question 1 . The results confirm all the e-payment factors/characteristics are good indicators of users' satisfaction with the e-payment system. The results reveal that the mean value of each factor is significant thereby indicating that they all have the potentials and capacity to determine users' satisfaction with e-payment. From the results, it can be infer that staff are generally satisfied with the speed of the e-payment system (Mean $=3.84$ ). The results thus answer the research question by revealing perceived speed as the e-payment characteristics users mostly satisfied with, followed by system security, traceability, and convenience. This answers research question one in this study.

Staff were asked to show their level of satisfaction with e-payment system on a four point ratings. Table 4 presents the results which reveal that staff were generally satisfied with the e-payment system at the University of Ilorin, Nigeria. Overall, more than half the population of the respondents (93.5\%) were adequately satisfied, satisfied and moderately (the highest level of satisfaction), while on the other hand, only $(6.5 \%)$ of the respondents were less satisfied and dissatisfied. This provides answer to research question two in this study.

Table 5 shows the descriptive statistics for the constructs and for the individual questionnaire items, respectively. The constructs shows high agreement with the items within Perceived speed $($ mean $=3.78)$, Perceived security $($ mean $=3.26)$, Anonymity $($ mean $=3.12)$, traceability (2.78), Perceived ease of payment EOP (mean $=2.61)$, and convenience $($ mean $=2.50)$. Table 2 also shows the inter-correlation between all the e-payment factors (i.e. characteristics) and e-payment users' satisfaction. The data suggests the absolute value greater than 0.05 which 
Table 2: Demographic Information of the Respondents $(N=260)$

\begin{tabular}{|c|c|c|}
\hline Demographics & Frequency & Percentage $\%$ \\
\hline \multicolumn{3}{|l|}{ Gender } \\
\hline Male & 146 & 56.2 \\
\hline Female & 114 & 43.8 \\
\hline Total & 260 & 100.0 \\
\hline \multicolumn{3}{|l|}{ Age } \\
\hline $21-30$ years & 55 & 21.2 \\
\hline 31- 40 years & 55 & 21.2 \\
\hline 41- 50 years & 60 & 23.1 \\
\hline $51-60$ years & 70 & 26.9 \\
\hline 61 years + & 20 & 7.8 \\
\hline Total & 260 & 100.0 \\
\hline \multicolumn{3}{|l|}{ Working Experience } \\
\hline $0-10$ years & 110 & 42.3 \\
\hline $11-20$ years & 90 & 34.6 \\
\hline 21-30 years & 35 & 13.5 \\
\hline 31 years + & 25 & 9.6 \\
\hline Total & 260 & 100.0 \\
\hline \multicolumn{3}{|l|}{ Respondents Types } \\
\hline Academic staff & 158 & 60.8 \\
\hline Non-academic staff & 102 & 39.2 \\
\hline Total & 260 & 100.0 \\
\hline \multicolumn{3}{|l|}{ Educational Level } \\
\hline $\mathrm{OND} / \mathrm{NCE}$ & 100 & 38.5 \\
\hline Bachelor Degree & 60 & 23.1 \\
\hline Master's Degree & 50 & 19.2 \\
\hline $\mathrm{PhD}$ & 50 & 19.2 \\
\hline Total & 260 & 100.0 \\
\hline
\end{tabular}

Table 3: Dimension of User satisfaction with e-payment $(\mathrm{N}=260)$

\begin{tabular}{|c|c|c|}
\hline Dimensions & Number of respondents & Mean \\
\hline Perceived security & 260 & 3.45 \\
Perceived speed & 260 & 3.84 \\
Ease of payment & 260 & 2.74 \\
Convenance & 260 & 2.40 \\
Anonymity & 260 & 3.38 \\
Traceability & & \\
\hline
\end{tabular}


Table 4: Overall Level of E-payment Satisfaction $(N=260)$

\begin{tabular}{|c|c|c|}
\hline Level of satisfaction & Number of Responses & Percentage \\
\hline Adequately Satisfied & 168 & 64.6 \\
Satisfied & 48 & 18.5 \\
Moderately Satisfied & 27 & 10.4 \\
Less Satisfied & 12 & 4.6 \\
Dissatisfied & 5 & 1.9 \\
\hline Total & 260 & 100 \\
\hline
\end{tabular}

Table 5: Descriptive statistics and Pearson correlation coefficient among dimension of satisfaction with E-payment System $(N=$ 260)

\begin{tabular}{|c|c|c|c|c|c|c|c|c|c|}
\hline Dimension & Mean & $\begin{array}{l}\text { Std. } \\
\text { Dev. }\end{array}$ & EPS & $\begin{array}{l}\text { Per. } \\
\text { Sec }\end{array}$ & $\begin{array}{c}\text { Per. } \\
\text { Speed }\end{array}$ & EOP & Conv. & Anonymity & Traceability \\
\hline E-payment system & 3.99 & 2.11 & 1.000 & & & & & & \\
\hline Perceived Security & 3.26 & 1.09 & $.544 * *$ & 1.000 & & & & & \\
\hline Perceived Speed & 3.78 & 1.27 & $.744 * *$ & .411 & 1.000 & & & & \\
\hline Ease of payment & 2.61 & 1.05 & $.442 * *$ & .569 & .644 & 1.000 & & & \\
\hline Convenience & 2.50 & 1.80 & $.533 * *$ & .599 & .467 & .787 & 1.000 & & \\
\hline Anonymity & 3.12 & 1.20 & $.478 * *$ & .588 & .446 & .557 & .608 & 1.000 & \\
\hline Traceability & 2.78 & 1.22 & $.380 * *$ & .137 & .422 & .544 & .465 & .129 & 1.000 \\
\hline
\end{tabular}

is considered positive. This indicates that there is a significant correlation between the three of the e-payment factors (Per. speed $r=0.744$; Per. sec $r=0.544$ and Convenience $\mathrm{r}=0.533)$.

The correlation ' $r$ ' of these three factors are greater than $=0.5$ while the correlation of the other three (Anonymity $r=0.478$, EOP $r=0.442$, and Traceability $r=$ 0.380 ) are partially weak. In terms of the inter-correlation (e.g. Per. sec. vs traceability $r=0.137$ and anonymity vs traceability, $\mathrm{r}=0.129$ ) reported weak correlation, where $\mathrm{P}$ $>0.05$. This provides answer to the third research question on this study thereby indicating that significant correlation exist between the entire e-payment factors and e-payment satisfaction.

Table 6 suggests that the $\mathrm{R}$ square $=0.71, \mathrm{R}$ value adjusted $=0.55$, and the multiple correlation of all the e-payment factors yielded an $\mathrm{R}=.046$. In the second step, the analysis of variance performed on multiple regression yielded an F-ratio value of 12.29. This was significant at 0.05 levels. The R Square results explained $71 \%$ variance of the dependent variable by independent variables. This suggests that all the six factors jointly determine users' satisfaction with the e-payment system. This provides answer to the fourth research question in this study.
Table 7 suggests that each of the independent variables (factors) made a significant prediction of e-payment system satisfaction. Arranging the values in order of magnitude of the prediction/contribution to e-payment users' satisfaction, perceived speed made the most significant prediction/contribution with $($ Beta $=0.14641, \mathrm{t}=4.211)$. The next predicting value or contribution was exerted by perceived security (Beta $=0.14863, \mathrm{t}=3.385$. This is followed by anonymity $($ Beta $=0.17211, \mathrm{t}=3.235)$. The other factors made a significant prediction/contribution in the following order: convenience (Beta 0.17374, $\mathrm{t}=3.113$ ); and traceability $($ Beta $=0.15518 ; \mathrm{t}=3.111)$. This suggests that all the factors contribute significantly to users' satisfaction with e-payment system; thereby provides answer to the fifth research question in this study.

\section{Discussion of Findings}

So far the results have shown that a greater percentage of the respondents $(93.5 \%)$ were adequately satisfied, satisfied and moderately satisfied with the e-payment system thereby provide answer to the first research question in the study. Perceived speed was revealed as the characteristics users mostly satisfied with, followed by system security, 
Table 6: Multiple Regression on Dimension of Users'Satisfaction with E-payment System $(N=260)$

\begin{tabular}{|c|c|c|c|c|}
\hline $\begin{array}{l}\text { Multiple R } \\
\text { R Square } \\
\text { Adjusted R. Square } \\
\text { Standard Error }\end{array}$ & $\begin{array}{l}.4581 \\
.7158 \\
.5449 \\
.1540\end{array}$ & Analysis of Varia & & \\
\hline & Df & Sums of Square & Mean Square & $\mathbf{F}$ \\
\hline $\begin{array}{c}\text { Regression } \\
\text { Residual } \\
\text { Total }\end{array}$ & $\begin{array}{c}5 \\
255 \\
260\end{array}$ & $\begin{array}{c}7223.828 \\
11.521\end{array}$ & $\begin{array}{c}36119.14 \\
2937.86\end{array}$ & 12.29 \\
\hline
\end{tabular}

Table 7: Co-efficient of the Prediction $(N=260)$. **Significant at 0.05 .

\begin{tabular}{|c|c|c|c|c|c|}
\hline Dimensions/variables & B & SE.B & Beta & t. & Sig. T \\
\hline Perceived Security & .11895 & .05114 & .14863 & 3.385 & $\mathrm{~S}^{* *}$ \\
Perceived Speed & .01107 & .05439 & .14641 & 4.211 & $\mathrm{~S} * *$ \\
Ease of payment & .03972 & .05909 & .14968 & 3.007 & $\mathrm{~S} * *$ \\
Convenience & .04789 & .06617 & .17374 & 3.113 & $\mathrm{~S}^{* *}$ \\
Anonymity & .01469 & .06453 & .17211 & 3.235 & $\mathrm{~S}^{* *}$ \\
Traceability & .01445 & .06842 & .15518 & 3.111 & $\mathrm{~S} * *$ \\
Constant (Users' satisfaction) & 31.20589 & 3.18019 & & 5.342 & 000 \\
\hline
\end{tabular}

traceability, and convenience. This provides answer to the second research question. Moreover, the results demonstrated significant correlation among all the factors (perceived speed, security, anonymity, traceability, perceived ease of payment, and convenience) and e-payment users' satisfaction. This hereby provides answer to the third research question. The results also suggest that all six factors jointly determine or predict users' satisfaction with the e-payment system. This also provides answer to the fourth research question. Finally, all the factors significantly contribute to users' satisfaction with e-payment system thereby provides answer to the fifth research questions in the study.

This result corroborates the earlier report by (Adewoye and Oni, 2010) who indicated that perceived ease of use is one of the antecedents of e-banking acceptance, and that there are other factors attracting customers to use e-banking system such as organizational reputation, perceived risk and trust. Similar to Adewoye and Oni's report, aside of perceive ease of payment, other factors indicated motivate respondents satisfaction with e-payment system are perceived speed, security, anonymity, traceability, and convenience.

A related finding was reported by (Saha et al., 2010) who reported many factor as correlates of e-government success such as efficiency, actual usage and discrepancy. However, none of these factors is relevant to the one identified as correlated to e-payment system in the present study. This variation may be due to the difference in the information system focused by each of the study. While the current study focused on e-payment system the former focused on e-government. It is also noted that the current study sought to determine satisfaction with the e-payment system while the former attempt to determine the e-government success.

A similar report was put forward by Chen, et al, (2009). According to these authors, consumers' satisfaction influenced continuance intention, while the perceived usefulness, subjective norm (SN), perceived ease of use, and perceived behavioural control (PBC) simultaneously influence satisfaction. Similarly optimism and innovativeness were reported as the significant motivators of satisfaction. It could be seen from this finding that factors similar to the ones identified in the current study were reported such as perceived ease of use. The fact that perceived ease of use is a common factor identified by many studies, indicate that it is a strong factor influencing or determining information system satisfaction.

Generally, it is clear from this discussion that many previous studies confirm perceived ease of payment factor which is one of the factors indicated in this study as determining satisfaction. This is not to say that other factors are not important. Therefore, future research should reconsider including the remaining factors in the future relevant 
studies to further determine their relevance in determining e-payment satisfaction and satisfaction with other information systems.

\section{Conclusion}

The results in this study have revealed that respondents are satisfied with the e-payment system for the payment of salaries at the University of Ilorin. Therefore, the vacuum of not knowing whether or not respondents are satisfied with the e-payment system introduced by the university two years ago has now being filled. Furthermore, the study has successfully confirms the six factors identified in the study as good determinant of e-payment system. This also has bridged the gap of unknown factors that have the likelihood of determining e-payment system in the mandatory environment. Similarly, this study has been able to add to the existing limited research and study on e-payment system in the Nigeria context.

Since the results in this study has demonstrated that some respondents are less satisfied with the e-payment system, it is recommended that there should be improvement on the e-payment system at the University so that all the stakeholders could be satisfied.

Traceability made the lowest significant contribution to the prediction of e-payment satisfaction. Meaning that, currently, users find it difficult to trace errors arising from using e-payment system. In the light of this, it is suggested that traceability should be more facilitated and the concerned stakeholders - the university and the banks involved should see to it that errors are effectively trace to assist e-payment users anytime they encounter errors in transaction or any other related challenges.

Considering the limitations of the study and future research direction, the sample was restricted mainly to academic environment, and therefore, most of the respondents were highly educated and have experienced regarding e-payment. In addition, results of the study might also be biased based on the sample selected only from academic environment. Therefore, involving more diverse e-payment users, such as older, less educated, and less experienced in another context different from academic environment, may enable the construction and validation of more generalized model.

Some characteristics of the system service, such as control which can also influence e-payment system success, were excluded in the study. Therefore, future research should consider including additional applicable factors such as system control for better understanding of e-payment system satisfaction. The measures for the construct of e-payment system satisfaction used in this study are self-reported. In this regards, future research can develop more objective and accurate measures for e-payment system satisfaction.

The analysis and classification of the publications were based on the parallel assessments of very few researchers. A parallel analysis by more researchers could have increased the results' validity.

The limited respondents used as sample of the study denied the opportunity of generalising the results in this study to other universities in Nigeria and to universities in Africa and other developing countries. However, the results in this study have laid the foundation on which other relevant research can improved upon.

\section{Practical Implications}

The study's findings make it possible for the information system users and the adoption organization to understand the e-payment satisfaction factors with which to improve the system and to prioritize their investments accordingly. Empirical revelation of factors that lead to user satisfaction with e-payment system will advance the development of theories in this area and present a basis for further research in this field.

\section{Literature}

Abrazhevich, D. nd*. A survey of user attitudes towards electronic payment systems. A Research Paper, IPO, Center for User-System Interaction, Technical University of Eindhoven, the Netherlands.

Adeoti, O., \& Osotimehin, K. (2012). Adoption of Point of Sale Terminals in Nigeria: Assessment of Consumers' Level of Satisfaction. Research Journal of Finance and Accounting, 3(1), 1-6.

Adewoye, J.O. (2013). Impact of Mobile Banking on Service Delivery in the Nigerian Commercial Banks. International Review of Management and Business Research, 2(2), 333-344.

Alao, A.A., \& Sorinola, O.O. (2015). Cashless policy and customers' satisfaction: A study of commercial banks in Ogun State, Nigeria. Research Journal of Finance and Accounting, 6 (2), 37-47.

Anderson, M. (1998). The electronic check architecture. Financial Services Technology Consortium.

Athanassopoulos, A. (2000). Customer satisfaction cues to support market segmentation and explain switching behaviour. Journal of Business Research, 47(3), 191207.

Ayo, C. K., Adewoye J. O, \& Oni A. A. (2010). The state of e-Banking implementation in Nigeria: A post-consolidation review. Journal of Emerging Trends in Economics and Management Sciences (JETEMS), 1(1), 37-45

Bailey, J., \& Pearson, W. (1983). Development of a tool for measuring and analyzing computer user satisfaction. Management Science, 29 (5), 530-545, http://dx.doi. org/10.1287/mnsc.29.5.530

Beerli, A., Martin, J.D., \& Quintana, A. (2004). A model 
of customer loyalty in the retail banking market. European Journal of Marketing, 38(1/2), 253-75, http:// dx.doi.org/10.1108/03090560410511221

Cavarretta, F., \& de Silva, J. (1995). Market overview of the payments mechanisms for the Internet Commerce. Global Journal of International Business Research, 2(2), 21-30.

Chavosh, A. Halimi, A. B., \& Espahbodi, S. (2011). Comparing the Satisfaction with the Banks E-Payment Services between Degree Holder and Non-Degree Holder Customers in Penang-Malaysia. International Journal of e-Education, e-Business, e-Management and e-Learning, 1(2), 132-138, http://dx.doi.org/10.7763/ IJEEEE.2011.V1.21

Chen, S.C, Chen, H.H., \& Chen, M.F. (2009). Determinants of satisfaction and continuance intention towards self-service technologies. Industrial Management \& Data Systems, 109(9), 1248 - 1263, http://dx.doi. org/10.1108/02635570911002306

DeLone, W.H., \& McLean, E.R. (2003). The DeLone and McLean Model of information systems success: A tenyear update. Journal of Management Information Systems, 19(4), 9-30.

Doll, W. J., \& Torkzadeh, G. (1988). The measurement of end-user computing satisfaction. MIS Quarterly, 12(2), 259-274, http://dx.doi.org/10.2307/248851

Hamid, N.R.A, \& Cheng, A.Y. (2013). A risk perception analysis on the use of electronic payment systems by young adult. WSEAS Transactions on Information Science and applications, 10(1), 26-35.

Hussein, R., Abdu-Karim, N. S., Mohamed, N., \& Ahlan, A. R. (2007). The influence of organizational factors on information system success in e-government agencies in Malaysia. Electronic Journal of Information Systems in Developing Countries -EJISDC, 29(1), 1-17. Retrieved from http://www.ejisdc.org/ojs2/index.php/ejisdc/article/view/234/194

Irani, Z., Sivarajah, U., Molnar, A., \& Lee, H. (2014). A User Satisfaction Study of the London Congestion Charging e-Service. A Paper presented at the Twentieth Americas Conference on Information Systems, Savannah, Georgia, 7-10 August.

Ives, B., Olson, M.H., \& Baraudi, J.J. (1983). The measurement of user information satisfaction. Communications of the ACM, 26 (10), 785-793, http://dx.doi. org/10.1145/358413.358430

Jung-Yu, L. \& Ching-Tsung, L. (2008). What factors drive customer satisfaction with e-banking services? Pacific Asian Conference on Information System, PACIS Proceedings, Paper 84.

Khan, M.A. (2010). An empirical study of Automated Teller Machine service quality and customer satisfaction in Pakistani banks. European Journal of Social Sciences, 13(3), 333-344.

Komal S., S. (2009). Impact of ATM on customer satis- faction: A comparative study of SBI, ICICI \& HDFC bank. Business Intelligence Journal, 2(2), 276-87. Retrieved from http://www.saycocorporativo.com/saycoUK/BIJ/journal/Vol2No2/article2.pdf

Leblanc, G. (1990). Customer motivation: use and non-use of automated banking. International Journal of Bank Marketing, 8(4), 36-40, http://dx.doi. org/10.1108/02652329010000901

Mobarek, A. (2007). E-Banking practices and customer satisfaction - A case study in Botswana. Paper Presented at the 20th Australasian Finance \& Banking Conference, http://dx.doi.org/10.2139/ssrn.1011112

Molla, A., \& Licker, P.S. (2001). E-Commerce Systems Success: An attempt to extend and respecify the DeLone and MacLean Model of IS success. Journal of Electronic Commerce Research, 2(4), 131-141.

Moutinho, L. (1992). Customer satisfaction measurements: prolonged satisfaction with ATMs. International Journal of Bank Marketing, 10 (7), 30-7, http:// dx.doi.org/10.1108/02652329210021131

Moutinho, L., \& Brownlie, D.T. (1989). Customer satisfaction with bank services: a multidimensional space analysis. International Journal of Bank Marketing, 7(5), 23-7, http://dx.doi.org/10.1108/02652328910131926

Murdock, G. W., \& Franz, L. (1983). Habit and perceived risk as factors in the resistance to use of ATMs. Journal of Retail Banking, 5(2), 20-29.

Olanipekun, W. D, Brimah, A.N. \& Ajagbe, S.T. (2013). Role of electronic banking in enhancing human resource performance and customer satisfaction: Evidence from Guaranty Trust Bank PLC, Nigeria. International Journal of Business and Behavioral Sciences, 3(4), 36-44.

Ong, C.S., Lai, J.Y., \& Wang, Y.S. (2004). Factors affecting engineers' acceptance of asynchronous e-learning systems in high-tech companies. Information \& Management, 41 (6): 795-804, http://dx.doi.org/10.1016/j. im.2003.08.012

Saha, P., Atanu N., \& Salehi-Sangari, E. (2010). Success of Government e-service delivery: Does satisfaction matter? Lecture Notes in Computer Science, 62 (28), 204215, http://dx.doi.org/10.1007/978-3-642-14799-9_18

Simmers, C.A. \& Anandarajan, M. (2001). User satisfaction in the internet-anchored workplace: an exploratory study. Journal of Information Technology Theory and Application, 3 (5), 39-53.

Stemper, R.G. 1990.The guide to successful consumer banking strategy, Chichester and Toronto: John Wiley \& Sons.

Tan, M. (2004). E-payment: The digital exchange. Singapore: Singapore University Press.

Tella, A. (2012). Determinants of E-Payment Systems Success: A User's Satisfaction Perspective. International Journal of E-Adoption, 4(3):15-38, http://dx.doi. org/10.4018/jea.2012070102 
Tella, A., \& Olasina, G. (2014). Predicting users' continuance intention toward e-payment System: An extension of the technology acceptance model. International Journal of Information Systems \& Social Change (IJISSC), 5(1), 47-67, http://dx.doi.org/10.4018/ ijissc. 2014010104

Tijani, J. A., \& Ilugbemi, A. O. (2015). Electronic payment channels in the Nigeria banking sector and its impacts on national development. Asian Economic and Financial Review, 5(3), 521-531.

Wan, W. W. N., Luk, C. L., \& Chow, C. W.C. (2005). Customers' adoption of banking channels in Hong Kong. International Journal of Bank Marketing, 23(3), 255272.

Wood, J. (2008). The effect of buyers' perceptions of environmental uncertainty of satisfaction and loyalty. Journal of Marketing Theory and Practice, 16 (4), 309-20.

Adeyinka TELLA is a senior lecturer in the Department of Library and Information Science, Faculty of Communication and Information Sciences, University of Ilorin, Nigeria. Tella is a commonwealth scholar who finished his PhD in September 2009 from the Department of Library and Information Studies; University of Botswana. In 2007, he was awarded small grant for thesis writing for the PhD students' category by the Council for the Development of Social Science Research in Africa (CODESRIA). He has written and published articles mostly in International reputable refereed journals together with chapters in books. He is one of the contributors to an information science reference "Cases on Successful E-learning Practices in the Developed and Developing World: Methods for the Global Information Economy". Tella has edited two books: 'Library and Information Science in Developing Countries: Contemporary Issues' published in 2013 and 'Social Media Strategies for Dynamic Library Service Development' published in 2015. Currently, he is the Associate Editor, International Journal of Library and Information Science, and Editor-in-Chief- International Journal of Information Processing and Communication (IJIPC). His research areas include e-learning, information literacy, information system management and evaluation, information communication technology, psychology of information, etc.

Abdulmumin ISAH is a lecturer in the Department of Library and Information Science, University of Ilorin, Nigeria. He has previously worked as Graduate Research Assistant on World Bank Research Project at the University of Lagos, Nigeria and College Librarian at the Nigerian Television College, Jos. He is a member of professional associations such as Nigerian Library Association (NLA) and the Association of Nigeria Authors (ANA). 


\section{APPENDIX}

\section{E-PAYMENT SATISFACTION QUESTIONNAIRE}

Instruction

Dear respondents,

This questionnaire is designed to learn about your satisfaction with the use of E-payment system for the payment of workers' salary in this university and other uses. It is purely for research exercise. Please answer each statement below by ticking the option that best reflects your degree of agreement or disagreement with that statement. There is no right or wrong answer. Your response will be treated with strict confidence. Thank you.

\section{Bio-Data Information}

Gender: Male

Female

Age: $21-30$ years

$31-40$ years

$41-50$ years

$51-60$ years

61 years +

Working Experience: 0-10 years

$$
21-30 \text { years }
$$

Staff: Academic Non -Academic

Educational Level: OND/NCE

Master's Degree Ph.D.

\section{SECTION B: E-payment Characteristics/Factors}

\begin{tabular}{|c|c|c|c|c|c|c|}
\hline $\mathbf{S} / \mathbf{N}$ & B1 - Perceived Security & SA & A & NS & D & SD \\
\hline 1 & E-payment system is the most secure payments: paying by invoice & & & & & \\
\hline 2 & With e-payment system, there is the fear that hacker can threats bank website & & & & & \\
\hline 3 & E-payment provides great security for salary payment/other transaction & & & & & \\
\hline 4 & The privacy and integrity of my personal information can be compromised & & & & & \\
\hline
\end{tabular}

Note: SA - Strongly Agree, A = Agree, NS = Not Sure, D = Disagree, SD = Strongly Disagree

\begin{tabular}{|c|c|c|c|c|c|c|}
\hline $\mathbf{S} / \mathbf{N}$ & B2 - Perceived Speed of E-payment & SA & $\mathbf{A}$ & NS & D & SD \\
\hline 1 & E-payment facilitates timely workers' salary payment & & & & & \\
\hline 2 & Receiving monthly salary is now very fast. & & & & & \\
\hline 3 & The speedy alert that salary has been paid is fantastic & & & & & \\
\hline 4 & Overall, I cherish receiving alert for early salary payment & & & & & \\
\hline $\mathbf{S} / \mathbf{N}$ & B3 - Perceived Ease Payment & SA & $\mathbf{A}$ & NS & D & SD \\
\hline 1 & E-payment makes salary payment easier than before & & & & & \\
\hline 2 & E-payment system has reduced errors in the payment of workers' salary to a barest minimum. & & & & & \\
\hline 3 & E-payment is rigid and inflexible & & & & & \\
\hline 4 & Overall, e-payment system is an easy means of salary payment & & & & & \\
\hline
\end{tabular}




\begin{tabular}{|c|c|c|c|c|c|c|}
\hline $\mathbf{S} / \mathbf{N}$ & B4 : Convenience & SA & A & NS & D & SD \\
\hline 1 & Using e-payment system is stress free & & & & & \\
\hline 2 & I don't need to appear in the bank physically before instructing transfer & & & & & \\
\hline 3 & It provides convenience of access as it is available $24 \mathrm{X} 7$ & & & & & \\
\hline 4 & E-payment effortless accessibility for differently abled people & & & & & \\
\hline
\end{tabular}

\begin{tabular}{|c|c|c|c|c|c|c|}
\hline $\mathbf{S} / \mathbf{N}$ & B5-Anonymity & SA & A & NS & D & SD \\
\hline 1 & I will continue using e-payment because of identity revelation during payment. & & & & & \\
\hline 2 & Would prefer that their purchases are registered to avoid disputes & & & & & \\
\hline 3 & Need of registration of purchases for a better service & & & & & \\
\hline 4 & There is concerned that vendors can register their purchases & & & & & \\
\hline
\end{tabular}

\begin{tabular}{|c|c|c|c|c|c|c|}
\hline $\mathbf{S} / \mathbf{N}$ & B6 - Traceability & SA & $\mathbf{A}$ & NS & D & SD \\
\hline 1 & Would not like to reveal information about source of income & & & & & \\
\hline 2 & E-payment system lacks standard format for remittance & & & & & \\
\hline 3 & Tracing errors could be very complex with e-payment & & & & & \\
\hline 4 & There is no way to verify that I am transacting with whom I intend to & & & & & \\
\hline
\end{tabular}

\begin{tabular}{|c|c|c|c|c|c|c|}
\hline $\mathbf{S} / \mathbf{N}$ & B7 - Satisfaction with E-payment System & SA & $\mathbf{A}$ & NS & D & SD \\
\hline 1 & The e-payment system is wonderful & & & & & \\
\hline 2 & The current e-payment system is stimulating & & & & & \\
\hline 3 & I am satisfied with this system because it's free from error & & & & & \\
\hline 4 & Overall, I am extremely satisfied receiving salary through e-payment system & & & & & \\
\hline
\end{tabular}

Please, indicate your level of satisfaction with the e-payment system by ticking appropriate option in the box below.

\begin{tabular}{|c|c|}
\hline Level of satisfaction & Tick as appropriate \\
\hline Adequately Satisfied & \\
Satisfied & \\
Moderately Satisfied & \\
Less Satisfied & \\
Dissatisfied & \\
\hline
\end{tabular}

